\title{
The application of statistical methods to indicators of triticale photosynthesis under chloride stress
}

\author{
(C) Viktor V. Ivanishchev \\ Department of Biology and Technologies of Living Systems. Tula State Lev Tolstoy Pedagogical University. \\ Lenin Ave., 125. Tula, 300026. Russia. Phone:+7 (4872)65-78-08.E-mail: avdey_VV@mail.ru
}

Keywords: triticale, shoots, chloride stress, photosynthesis, principal component analysis, cluster analysis.

Abstract
The paper presents the results of a study of the relationship between photosynthesis indicators of triticale shoots under conditions of short-term $\mathrm{NaCl}$ stress. For this, the principal component analysis (PCA) and cluster analysis were used. It was established that the characteristics of photosynthesis form three groups: (1) carbonic anhydrase and electron transport, (2) chlorophyll and carotenoids, (3) photosynthesis intensity. The correlation coefficients between the indicators are 0.85 and 0.97 for the first two groups, respectively. Using the cluster analysis method has led to similar results. Further analysis of the data with PCA for the characteristics of photosynthesis and oxidative stress showed that the indicators can also be combined into three groups: (1) stomatal conductivity, chlorine and sodium, (2) chlorophyll and carotenoids, (3) photosynthesis intensity and Rubisko activity. For physiological and biochemical parameters, the highest correlation coefficients were as follows: electron transport -lipid peroxidation (0.98), chlorophyll - carotenoids (0.97), carbonic anhydrase - LPO (0.86), carbonic anhydrase - electron transport (0.85), electron transport - hydrogen peroxide (0.63), LPO hydrogen peroxide (0.62). The cluster analysis method suggests a close relationship between electron transport and the accumulation of hydrogen peroxide, carbonic anhydrase and lipid peroxidation. Based on the results obtained, conclusions are drawn about the close relationship between the activity of carbonic anhydrase and electron transport, and the magnitude of lipid peroxidation under experimental conditions, which, however, requires direct experimental evidence of such connections.

\section{References}

[1] V.V. Ivanishchev. On the possibility of an applying the method of cluster analysis to results of physiological-biochemical investigations of plants. Proceedings of Tula State University. Natural Sciences. 2018. Iss.1. P.69-77. (russian)

[2] V.V. Ivanishchev. On the application of statistical methods in the study of stress in plants and their selection. The Bulletin of Kharkiv National Agrarian University. Series Biology. 2018. Iss.3(45). P.111118. https://doi.org/10.35550/vbio2018.03.111

[3] V.V. Ivanishchev, and N.N. Zhukov. Manifestations of oxidative stress in sprouts of triticale under condition of short-term exposure of sodium chloride. Butlerov Communications. 2017. Vol.52. No.11. P.123-130. DOI: 10.37952/ROI-jbc-02/17-52-11-123

[4] V.V. Ivanishchev, and N.N. Zhukov. On the interrelation of water exchange and photosynthesis in triticale sprouts with short-term action of sodium chloride. Butlerov Communications. 2018. Vol.53. No.3. P.35-42. DOI: $10.37952 / \mathrm{ROI}-\mathrm{jbc}-02 / 18-53-3-35$

[5] V.V. Ivanishchev. Investigation of the effect of short-term salt stress with the method of cluster analysis. Butlerov Communications. 2018. Vol.54. No.4. P.134-139. DOI: 10.37952/ROI-jbc-02/18-54-4-134

[6] Principal component analysis. http://xn--c1acc6aafa1c.xn--p1ai/?page_id=2252. (russian)

[7] D.A. Shabanov, M.A. Kravchenko. Statistical data analysis in zoology and ecology. 2011. https://batrachos.com/biostatistica.

[8] A.R. Garifzyanov, N.N. Zhukov, A.A. Kosobryukhov, V.V. Ivanishchev. Functional state of the photosynthetic apparatus triticale seedlings under chloride salinity. Proceedings of Tula State University. Natural Sciences. 2014. Iss.1(1). P.280-290. (russian)

[9] N.N. Bureeva. Multidimensional statistical analysis with an application of "STATISTICA" software package. Nyzhnii Novgorod: NNGU. 2007. 112p. (russian)

[10] V.V. Ivanishchev. Plant production process and its regulation. Tula: Publishing house L.N. Tolstoy TSPU. 2011. 114p. (russian) 
[11] G. Edwards, D. Walker. C3, C4: Mechanisms and Cellular and Environmental Regulation of Photosynthesis. Berkeley. 1983. 590p.

[12] H.W. Heldt, B. Piechulla. Plant Biochemistry (4 ed.). Amsterdam et al.: Academic Press is an Imprint of Elsevier. 2011. $647 \mathrm{p}$.

[13] N.N. Rudenko, L.K. Ignatova, T.P. Fedorchuk, B.N. Ivanov. Carbonic anhydrases of higher plant photosynthetic cells. Biochemistry (Moscow). 2015. Vol.80(6). P.798-813. (russian)

[14] D.S. Veselov. Stretch growth and water exchange in conditions of water scarcity. Abstract of Doctor Thesis for biol. sciences. Ufa. 2009. 47p. (russian)

[15] V.D. Kreslavski, S.I. Allakhverdiev, D.A. Los, V.V. Kuznetsov. Signaling role of reactive oxygen species in plants under stress. Russian Journal of Plant Physiology. 2012. Vol.59(2). P.141-154. (russian) 